\title{
How Healthy Is The Green FDI in India?
}

\author{
Samar Habib Khan., PhD \\ samarhabib@gmail.com \\ Assistant Professor, Emirates Canadian University College \\ Umm Al Quwain, UAE \\ Ahmed Al Hayek., PhD \\ Associate Professor, Emirates Canadian University College \\ Umm Al Quwai
}

\begin{abstract}
The concept of 'Green FDI' is not any older. The continuous threat of global warming and environmental degradation forced economists to raise the issue with an intention to step up the efforts of attracting and nurturing environmentally sound technology and practices. India is a power deficient and a fund scarce country. Government efforts to attract foreign investors in the non-conventional sector, considering it to be green, can bring more efficiency, technology and paced sustainable development to the economy. Present study is an attempt to prove the scope and compatibility of Green FDI with the total foreign investment in India. Considering the infancy of identified field, a different approach of assessment has been adopted. Association of green FDI and Eco- Destructive FDI with the total FDI has been acknowledged through Regression Analysis. Comparison of relationship with the contradictory sectors helped in reaching the conclusion effectually. Results provided that the FDI in non-conventional energy in India does have a long term and stronger relationship with total foreign investment which eventually verifies pink and healthy future of Green FDI in the country.
\end{abstract}

Key Words: Green FDI, Non-conventional Energy, Eco-destructive Sector, Sustainable development

\section{Introduction}

The foreign investment by way of direct route or through portfolio is among the most popular and favorite sources of fund for almost every country. One of the basic reason for that attraction is the cost of finance attached to them. In Foreign Institutional Investment (FII) which is done by way of investment in the portfolio of the host country business, the management usually remains in the hands of the host equity owner but in Foreign Direct Investment (FDI) the concerned business is mainly controlled by the foreign investor himself and this is the reason that the return of such fund is rather more dependent over the performance of the investor than to the host country, making

the option of FDI be more attractive than FII or any other source of foreignfunds.

The concept of 'Green FDI' is not any older. The continuous threat of global warming and environmental degradation forced economists to raise the issue with an intention to step up the efforts of attracting and nurturing environmentally sound technology and practices. This resulted in the growth of business in environmental products in a dramatic way. Although there is still a lack of internationally agreed definition of the term 'Green FDI' but to sum up on the basis of

Journal of Research in Administrative Sciences (JRAS)

VI(I) 24-28, ISSN: 2664-2433 various literature reviews it can be explained as "Direct investment by the foreigners within the sectors where the scope of sustainable development and green effect is greatest." Another apprehension after unavailability of any standard explanation or definition of green FDI is the concern that majority countries are still unable to track the record of FDI at such an integrated level. Yet, India is an exception making the records since 2006- $07^{1}$ about the monthly data of FDI inflows in green field naming the sector as "non- conventional energy" sector. The sub sectors it has considered for the purpose are, Photo-voltaic, Solar Thermal, Solar, Small Hydro, Geothermal, Biomass, Co-generation, Wind, Tidal and Urban \& Industrial Wastes based power projects. ${ }^{2}$

This study is mainly an effort to know as how healthy such effort of the government is? Considering the infancy of identified field, a different approach of assessment has been adopted. A relationship has been identified between the contribution of green FDI towards total FDI and contribution of eco-destructive FDI towards total FDI. Then conclusion has been drawn as which among them, green or eco-destructive sector, is more active participant towards the total foreign investment in the country.

For the purpose of Green FDI, data related to non-conventional 
energy has been considered ${ }^{3}$ and as for eco-destructive FDI, six industries have been considered viz; Petroleum and natural gas, Paper and Pulp, Construction development, Chemicals, Metallurgic industries and Mining industry. Inspiration of such choice is relying consistently on U.S. data for "dirty" industries, either on the basis of expenditure cut costs or on emissions of pollutants ${ }^{4}$ as well as classification of 'Red' industries by the Indian Ministry of Environment and Forests under SCHEDULE-VIII [rules 3(2) and 12] ${ }^{5}$. Six common industries among the list of these two heads, dirty and red, were under observation.

\section{Research Methodology}

The study is conducted by collecting secondary data from various sources of information like World Data Bank, Sia Newsletter and some literature reviews. The problem of research has been identified as how effective the government efforts of promoting sustainable development through foreign investment is? A Regression Analysis is conducted with green FDI and the eco-unfriendly FDI as an independent variable and total FDI as an independent variable.

\section{Literature Review}

According to Renewable Energy Policy Network (REN21) 6 , in the coming decades the pollution threat will become a fundamental challenge to the world economy and especially financial industry. But the future can be seen with totally different standpoint through the dynamic nature of renewable energy markets, technologies, and cost reductions continuation.

G. Maria and M. Reinhard ${ }^{7}$ offers a Russian perspective over the importance of FDI for energy efficiency and carbon mitigation projects. It is believed that apart from capital generation, transfer of technology and new job opportunities creation, the importance of FDI should also be acknowledged in the context of sustainable growth and com,

S. Yue, Y. Yang and Y, Hu ${ }^{8}$ in their published article has profoundly explained as how FDI not only effects the economic growth but also effects the environmental protection of the host country. It has been observed within the context of Chinese economy that when the total green efficiency of the country is split up into economic efficiency and environmental efficiency then FDI encourages it through both (environmental and economic) way.

Talking about India in specific Golub, S. S., C. Kauffmann and P. Yeres ${ }^{9}$, in their working paper on international investment, remark that although for categorizing FDI in green, record of Environmental Goods and Service (EGS) could be measured. However, most countries do not make a proper record and report of data on such a segregated level with India as an exception. The country directly promotes green FDI by providing many investment incentives as well as subsidies.

\section{Green FDI in India}

The search of green energy has started in India since early 70 's of the last century. Subsequently the two main areas recognized were 'efficient use of energy' and 'usage of renewable energy sources'. To give a strenuous effort to the identified field, in 1981 the government of India made a Commission for Additional Sources of Energy (CASE) in the Department of Science and Technology 10 .

The Central government of India also boosted the FDI in this sector through Build-Own- Operate basis, where the process of investment approval has been liberalized by allowing 100 percent FDI in case of equity in the concerned field. Foreign investors have prospects of capitalizing in renewable energy fields such as Biomass, Rural electrification, Hydropower, Wind, Tidal and Urban \& Industrial Wastes based power projects etc. $^{11}$

The glimpse of recent trend of FDI in non-conventional energy since its inception of records is as follows:

Table:1. Year-Wise FDI Inflows Under Non-Conventional Energy 2006-2015

\section{Green FDI}

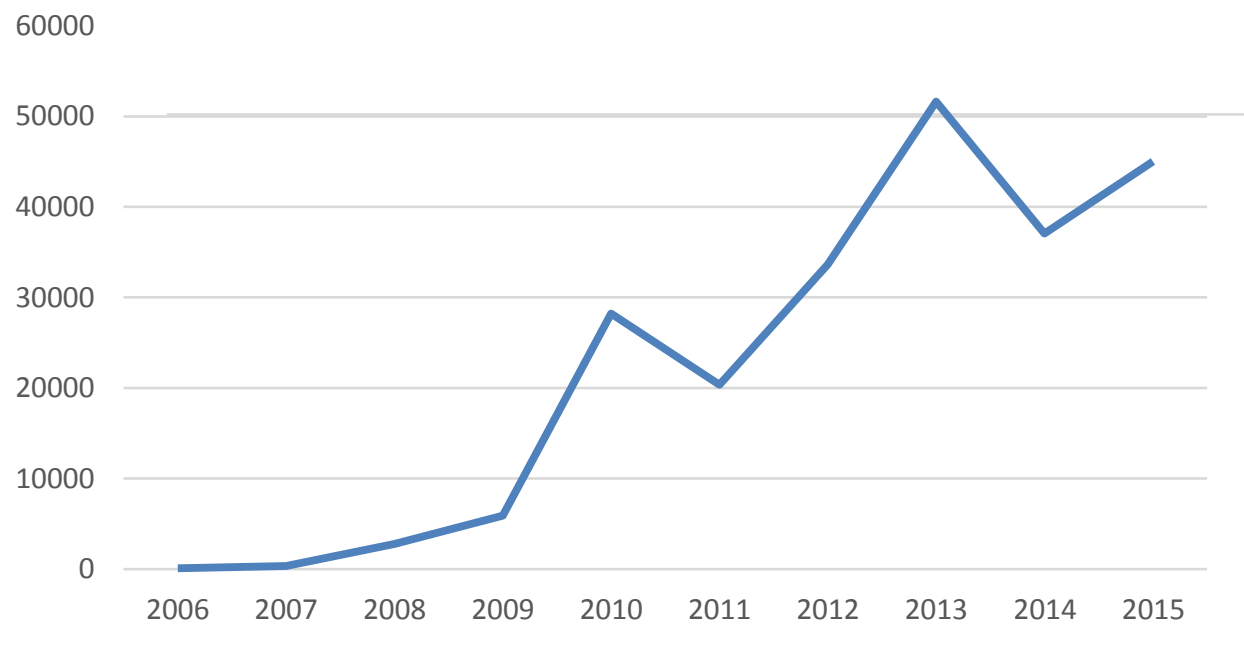

Source: SIA newsletters ${ }^{17}$ 
The continuous growth in the field is real inevitable. From 2006 when it was first recorded the amount was Rs 319.83 m which reached to its highest in 2013 with a figure of Rs $51635.67 \mathrm{~m}$. India ranked $5^{\text {th }}$ in $2015^{\mathbf{1 2}}$ and then $3^{\text {rd }}$ in 2016 in the Renewable Energy Country Attractiveness Index, with the potential of $749 \mathrm{gw}$ in Solar, 102.8gw in wind, $22.5 \mathrm{gw}$ in biomass and $19.7 \mathrm{gw}$ in Small hydro ${ }^{13}$.

\section{Eco-destructive FDI}

On the basis of observation performed by many studies on trade and environmental regulations, a set of 'dirty' industries have been recognized as an eco-destructive forces for the country. Although definition and criteria of listing may vary but some of the industries tend to be listed in everyone's list. Our choice of industries and sectors for eco destructive industries is finalized by comparing the international list of dirty industries $\mathbf{1 4}$ with the Indian industries classified as 'Red' industries by the ministry of environment and forests under SCHEDULE-VIII [rules 3(2) and 12] ${ }^{\mathbf{1 5}}$. Six common industries among them viz; Petroleum and natural gas, Paper and Pulp, Construction development, Chemicals, Metallurgic industries and Mining industry, have been chosen for the study.

Trend of FDI flow through these industries in the observed period is as follows:

Table:2. Year-Wise FDI Inflows Under Eco-Destructive Sectors 2006-2015

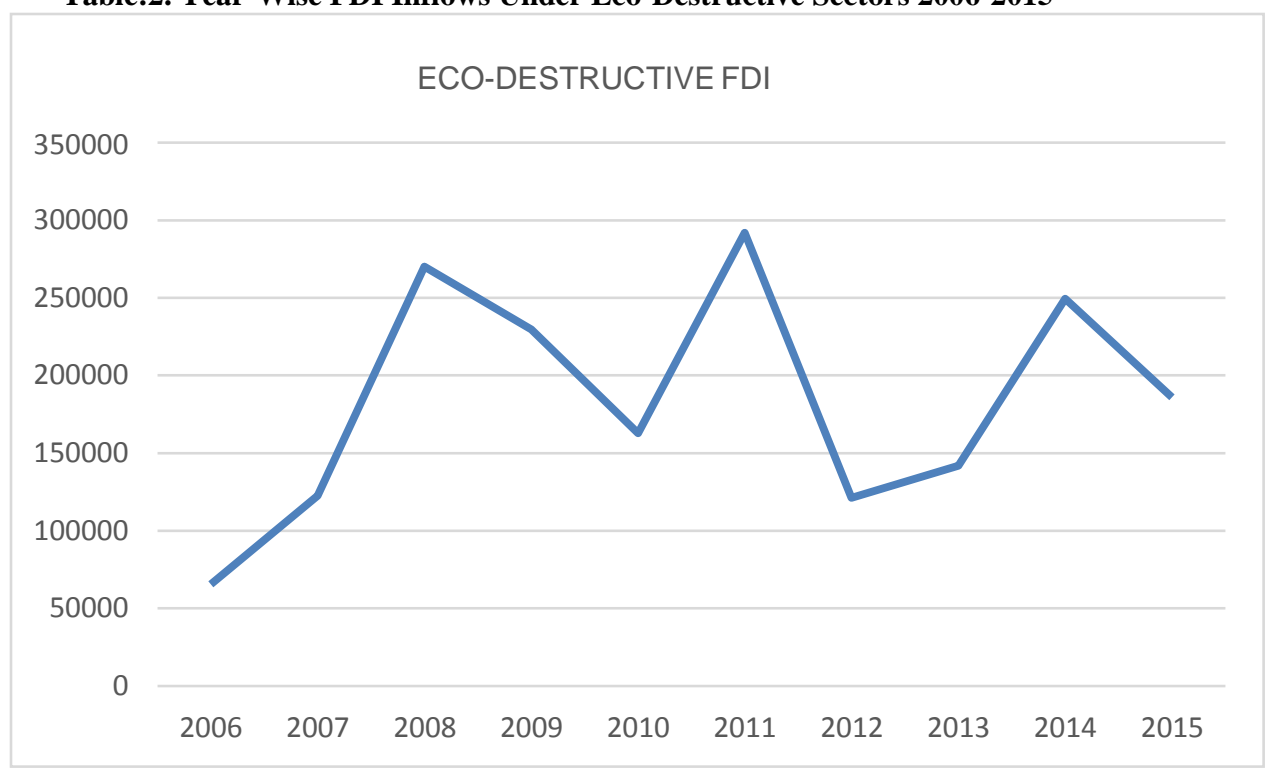

Source: Computed by the research scholar through the data calculated from SIA newsletters

Unlike the Green FDI, graph of eco-destructive FDI is extremely fluttered. The trend is not easy to interpret with this fluctuation as an example of sharp growth in 2011 with Rs 291967.45 and then sudden steep downfall in 2012 with Rs 121278.54 but again reaching quite high in 2014 with Rs. 249490.93. This variation could be because of unfriendly business climate, complicated tax structure or restrictive labor law and regulations for the concerned firms. 16

\section{Results}

The Regression analysis is used to investigate the causal effect between predictor and response variables. The predictor variables here are Green FDI and Eco-destructive FDI whereas response variable is the total FDI of the country. Graphically and numerically the total amount contributed to FDI by ecodestructive FDI (14\%) is much more than green FDI (2\%) ${ }^{17}$ but when it comes to see the compatibility through statistical results the picture seems different. 
Table: 3. Results of Regression Analysis with Predictor and Response Variables

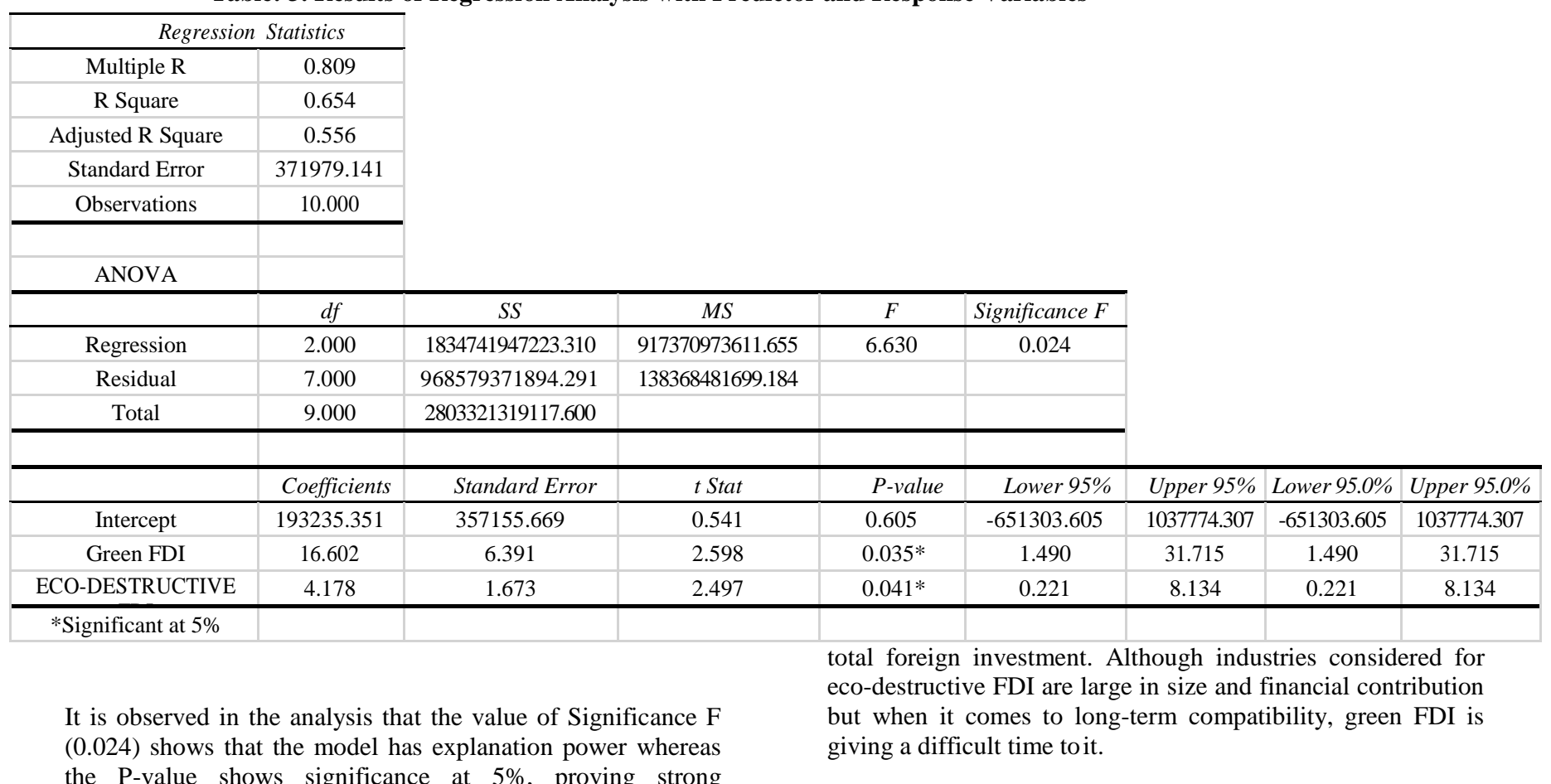
relationship of both the ind variable. Although numerically, green FDI is a way lesser contributor towards total FDI but through P-value it is proven that the green FDI has got a very competitive affect with percentage of relationship as $96.4 \%$ compare to $95.5 \%$ for eco-destructive FDI.

Based on various literature and activities reviews it is discernible that although almost every other developed and developing country like Russia or China is making serious efforts to concentrate on Green FDI, the efforts of Indian government in the concerned field is still inimitable. Having a separate sector, the country has $3^{\text {rd }}$ highest investment in nonconventional energy with $100 \%$ FDI through automatic route with US\$2.5 billion FDI inflows from 2000-2013. ${ }^{12}$

\section{Conclusion}

India is a power deficient and a fund scarce country. Government efforts to attract foreign investors in the nonconventional sector can bring more efficiency, technology and paced sustainable development to the economy. The Central government of India has also boosted the FDI in this sector through Build-Own-Operate basis, where the process of investment approval has been liberalized by allowing 100 percent FDI in case of equity in the concerned field.

Present study has been conducted to prove the scope and compatibility of non- conventional sector within the total foreign investment in the country. Due to early stage of identified field, instead of directly comparing the performance, a different approach is adopted. Association of green FDI and eco-unfriendly FDI has been acknowledged with the total FDI. Results are proving that the FDI in nonconventional energy does have a long-term relationship with

\section{References}

i. Golub, S. S., C. Kauffmann and P. Yeres (2011), "Defining and Measuring Green FDI: An Exploratory Review of Existing Work and Evidence", OECD Working Papers on International Investment, 2011/02, OECD Publishing.

ii. http://www.makeinIndia.com/sector/renewable-energy

iii. http://www.altenergymag.com/content.php?post_type= 1654

iV. http://www.nber.org/chapters/c9537.pdf

V. http://envfor.nic.in/legis/ucp/ucpsch8.html

vi. http://www.ren21.net/future-of-renewables/globalfutures-report/

vii. Garbuzova-Schlifter, M., \& Madlener, R. (2011), "Towards an Efficient and Low- Carbon Economy Post-2012: Opportunities and Barriers for Foreign Companies in the Russian Market".

viii. Yue, S.; Yang, Y.; Hu, Y. Does Foreign Direct Investment Affect Green Growth? Evidence from China's Experience. Sustainability2016, 8, 158.

iX. Golub, S. S., C. Kauffmann and P. Yeres (2011), "Defining and Measuring Green FDI: An Exploratory Review of Existing Work and Evidence", OECD Working Papers on International Investment, 2011/02, OECD Publishing.

X. http://mnre.gov.in/information/policies-2

xi. http://business.mapsofIndia.com/fdi-India/sectors/nonconventional- energy.html\#sthash.i447hjSp.dpuf

Xii. MNRE; RE-Invest 2015 Investor Guide; Invest India 
analysis

Xiii. http://www.ey.com/Publication/vwLUAssets/EY-

RECAI-47-May-2016-index-at-a-

glance/\$FILE/EY-RECAI-47-May-2016-index-at-aglance.pdf

xiv. http://voxeu.org/article/trade-pollution-and-

environment-new-evidence http://www.nber.org/chapters/c9537.pdf

XV. http://envfor.nic.in/legis/ucp/ucpsch8.html

XVi. http://www.ripublication.com/gjfmspl/gjfmv6n7_10.pdf

XVii. http://dipp.nic.in/English/Publications/SIA_NewsLetter/S IA_NewsLetter.aspx 